\title{
PENGEMBANGAN MAKANAN JAJANAN ANAK SEKOLAH MIE REBON BERBAHAN DASAR PANGAN LOKAL REBON DAN MOCAF SERTA UJI ORGANOLEPTIK
}

\author{
Wiwit Estuti $^{1}$, Uun Kunaepah ${ }^{2}$, Hendi Hendarman ${ }^{3}$
}

\begin{abstract}
ABSTRAK
Makanan jajanan sudah menjadi bagian yang tidak terpisahkan bagi anak sekolah dan menjadi kebiasaan sehari-hari. Kandungan zat gizi makanan jajanan bervariasi, tergantung bahan pembuatnya. Pembuatan makanan jajanan perlu memperhatikan kandungan gizi yang mencukupi sesuai anjuran pedoman PMT-AS dan perlu pengolahan higienis. Selain itu perlu adanya variasi dan peningkatan nilai gizi terutama protein bagi anak-anak usia sekolah untuk pertumbuhan dan perkembangannya. Sehingga diperlukan adanya upaya penganekaragaman pembuatan makanan jajanan yang lebih bervariasi dengan memanfaatkan bahan pangan lokal yang mempunyai kandungan protein cukup tinggi, salah satunya adalah tepung mocaf dan rebon. Penelitian ini bersifat eksperimental eksploratif yang dilakukan secara bertahap mulai dari persiapan bahan, formulasi, percobaan pengolahan dan pengujian organoleptik. Penelitian dilaksanakan dari bulan Maret-November 2014. Bahan-bahan yang digunakan yaitu tepung terigu, tepung mocaf, rebon diperoleh dari pasar tradisional di Kota Cirebon. Sementara itu juga digunakan alat-alat untuk mengolah dan uji organoleptik. Selanjutnya percobaan pengolahan mengikuti bagan alir penelitian. Hasil penelitian menunjukkan produk terbaik adalah mie rebon 2 dengan formulasi tepung terigu $80 \%$, tepung mocaf $20 \%$, dan rebon $10 \%$. Perlu dilakukan penelitian lanjutan untuk membuat mie dalam bentuk mie kering agar daya simpan mie lebih lama dan produk tersebut dapat dijadikan alternatif cemilan sehat bagi anak sekolah.
\end{abstract}

Kata Kunci : Makanan jajanan, mie rebon, mocaf.

\begin{abstract}
FOOD snacks already being an integral part of the school children and being for everyday habits. Snacks nutrient content varies, depending on the maker of materials. Keep snacks in Preparation food which sufficient attention to the nutritional content of As recommended guidelines PMT-AS And Need Treatment The hygienic. In addition need for variation and increase the nutritional value especially protein for children of school-age to grow and develop. Necessary for the diversification efforts Making snacks more utilize varied Local food ingredients That had the protein content of high, only prayer is flour Mocaf And rebon. The experimental research conducted exploratory that operates gradual starting material preparation, formulation, experimental treatment and organoleptic test. Organoleptic test performed in the laboratory of Food Technology and Nutrition Chemical at Diplom of Nutrition Cirebon. Research conducted of the month from March to November 2014. Substances used flour, mocaf, rebon From traditional market in the city of Cirebon. Further experiments follow flowchart Processing Research. Research shows that Best Product is Noodle of rebon 2 with formulation wheat flour 80\%, flour Mocaf 20\%, and 10\% Rebon. Research needs to be done significant. Noodles of rebon and products mentioned maybe an alternative healthy snack For school children.
\end{abstract}

Keywords: noodles of rebon, mocaf, snack food 


\section{PENDAHULUAN}

Program gizi pada kelompok anak sekolah memiliki dampak luas yang tidak saja pada aspek kesehatan, gizi dan pendidikan masa kini tetapi juga secara langsung mempengaruhi kualitas sumber daya manusia di masa mendatang. Anak sekolah merupakan sasaran strategis dalam perbaikan gizi masyarakat.Hal ini menjadi penting karena anak sekolah sedang mengalami pertumbuhan secara fisik dan mental yang sangat diperlukan guna menunjang kehidupannya di masa mendatang. Selain itu guna mendukung keadaan tersebut anak sekolah memerlukan kondisi tubuh yang optimal dan bugar sehingga memerlukan status gizi yang baik. Anak sekolah dapat dijadikan perantara dalam penyuluhan gizi pada keluarga dan masyarakat sekitarnya.

Karena pentingnya perbaikan gizi pada anak sekolah, maka pemerintah mengeluarkan Pedoman Penyediaan Makanan Tambahan Anak Sekolah berdasarkan Peraturan Menteri Dalam Negeri No. 18 tahun 2011. Berdasarkan peraturan tersebut Penyediaan Makanan Tambahan Anak Sekolah yang selanjutnya disingkat PMT-AS adalah kegiatan pemberian makanan kepada peserta didik dalam bentuk jajanan/kudapan atau makanan lengkap yang aman dan bermutu beserta kegiatan pendukung lainnya, dengan memperhatikan aspek mutu dan keamanan pangan.

PMT AS memerlukan partisipasi masyarakat secara aktif dalam setiap kegiatan pemberdayaan masyarakat dalam rangka memberikan tenaga, pikiran, dana, dan kontribusi lainnya. Adapun tujuan PMTAS adalah; meningkatkan kecukupan asupan gizi peserta didik melalui makanan tambahan; meningkatkan ketahanan fisik dan kehadiran peserta didik dalam mengikuti kegiatan belajar; meningkatkan kesehatan anak khususnya dalam penanggulangan penyakit kecacingan; meningkatkan pengetahuan dan perilaku peserta didik untuk menyukai makanan lokal bergizi, menerapkan Perilaku Hidup Bersih dan Sehat (PHBS) dan Lingkungan Bersih dan Sehat (LBS); meningkatkan partisipasi masyarakat dalam memanfaatkan dan pengadaan pangan lokal; dan meningkatkan kesadaran dan partisipasi masyarakat dalam upaya perbaikan gizi peserta didik, produksi pertanian, pendapatan masyarakat dan kesejahteraan keluarga.

Nilai gizi PMT Anak sekolah yang dianjurkan adalah Energi: 250 - 300 Kkal dan Protein: 5 - 10 gram sedangkan sasaran PMT-AS adalah peserta didik, orang tua peserta didik, guru, dan komite sekolah. Rebon merupakan bahan pangan lokal yang banyak dihasilkan di Kota Cirebon. Kandungan protein pada rebon segar (basah) adalah $16.2 \mathrm{~g}$ dan kalsium sebesar $757 \mathrm{mg}$ sedangkan pada rebon kering protein sebesar $29.4 \mathrm{~g}$ dan kalsium sebesar $2.306 \mathrm{mg}$. Kandungan protein dan kalsium yang terdapat pada rebon memberikan gambaran bahwa rebon adalah pangan yang mempunyai kriteria sebagai bahan pangan lokal yang tinggi kandungan protein dan kalsium. Rebon selama ini diolah oleh masyarakat sebagai makanan seperti rempeyek, dan lainnnya (Hardinsyah, dkk. 1994 dalam Estuti 2011).

Tepung mocaf (modified cassava flour) adalah tepung yang terbuat dari singkong yang mengalami proses fermentasi terlebih dahulu, sehingga didapatkan tepung yang memiliki sifat fisik (daya kembang) setara dengan tepung terigu tipe II (tepung terigu protein sedang). Tepung mocaf yang terbuat dari singkong juga memiliki kandungan kalsium lebih tinggi dibandingkan dengan tepung terigu dan lebih mudah dicerna (Dahlia, 2012).

Tepung mocaf dapat digunakan sebagai subtitusi tepung terigu untuk produk pangan dengan jumlah yang berbedabeda.Dalam pembuatan kue kering, Mocaf dapat menggantikan $100 \%$ tepung terigu (Salim, 2011). Namun, mocaf memiliki kekurangan yaitu kandungan proteinnya yang rendah dan tidak memiliki kandungan gluten seperti pada tepung terigu sehingga dalam aplikasinya diperlukan adanya 
penambahan zat gizi lainnya. Bahan pangan yang memiliki kandungan protein tinggi salah satunya adalah rebon.

Program penganekaragaman pangan merupakan cara penting untuk meningkatkan kecukupan gizi di tingkat pedesaan, regional dan nasional. Cara yang berbeda dalam pengolahan pangan untuk memberi variasi pangan yang bergizi merupakan bagian dari penganekaragaman pangan.(Suharjo, 1995 dalam Ratnawati, 2011).

Perkembangan konsumsi mie yang sangat pesat memberi pelajaran bahwa bahwa mie merupakan jenis makanan yang sesuai dengan kebutuhan dan preferensi konsumen Indonesia. Namun, di sisi lain berpeluang menurunkan devisa negara, mengingat mie merupakan produk yang terbuat dari tepung terigu, suatu komoditas impor. Sementara itu pembangunan pertanian nasional telah mampu menghasilkan beragam komoditas sumber karbohidrat lain yang perlu ditingkatkan pemanfaatannya, terutama dalam rangka penyediaan pangan alternatif bagi masyarakat (Sari, 2010).

Oleh sebab itu, perlu pengembangan teknologi mie berbahan baku tepung selain tepung terigu, salah satu contohnya dengan memanfaatkan tepung mocaf dalam pembuatan makanan jajanan untuk anak sekolah. Kombinasi mie basah ini dapat juga divariasikan dengan menggunakan bahan

\section{METODE PENELITIAN}

Penelitian ini merupakan penelitian eksperimen semu dengan perlakuan formulasi penambahan tepung mocaf, rebon dan sayuran serta pada pembuatan makanan jajanan anak sekolah mie sehat. Rancangan penelitianyang digunakan adalah dengan 3 (tiga) perlakuan dan 2 (dua) kali ulangan (6 unit percobaan).

Bahan-bahan utama yang digunakan dalam penelitian ini adalah rebon, tepung mocaf, tepung terigu, tepung maizena, telur, keju dan tepung gula/gula halus. Alat yang digunakan dalam pengolahan meliputi: pangan local sayuran local seperti wortel dan bayam yang banyak dihasilkan di Cirebon.

Makanan jajanan sudah menjadi bagian yang tidak terpisahkan bagi anak sekolah dan menjadi kebiasaan seharihari.Kandungan zat gizi makanan jajanan bervariasi, tergantung dari bahan pembuatnya.Dalam pembuatan makanan jajanan perlu memperhatikan kandungan gizi yang mencukupi sesuai anjuran pedoman PMT-AS dan perlu pengolahan yang higienis. Selain itu perlu adanya variasi dan peningkatan nilai gizi terutama protein bagi anak-anak usia sekolah untuk pertumbuhan dan perkembangannya. Dengan demikian diperlukan adanya upaya penganekaragaman pembuatan makanan jajanan yang lebih bervariasi dengan memanfaatkan bahan pangan lokal yang mempunyai kandungan protein cukup tinggi, salah satunya adalah tepung Mocaf dan rebon juga tambahan vitamin A pada wortel dan bayam.

Berdasarkan uraian di atas, maka dilakukan penelitian dengan tujuan mendapatkan Formulasi tepung mocaf, rebon, dan sayuran (wortel dan bayam) yang terbaik pada pembuatan makanan jajanan anak sekolah Mie sehat yang dapat dijadikan sebagai alternatif makanan tambahan bagi anak balita dilihat dari sifat organoleptik dan komposisi gizinya.

saringan tepung, mixer, oven, loyang, cetakan kue kering, kayu penggiling, sendok, spatula dan timbangan digital. Alat uji organoleptik yang digunakan meliputi: piring kertas dan formulir uji hedonic.

Data yang digunakan adalah data primer.Data primer diperoleh dari data Sifat Organoleptik dan data komposisi zat gizi. Pengumpulan data diperoleh dengan menggunakan form uji hedonic untuk sifat organoleptik dan komposisi zat gizi diperoleh dari hasil analisis proksimat. 
Tabel 1. Rancangan Percobaan Penelitian

\begin{tabular}{ccccc}
\hline \multirow{2}{*}{ Ulangan } & \multicolumn{5}{c}{ Perlakuan } \\
\cline { 2 - 5 } & $\mathrm{A}$ & $\mathrm{B}$ & $\mathrm{C}$ & $\mathrm{D}$ \\
\hline 1 & $\mathrm{~A} 1$ & $\mathrm{~B} 1$ & $\mathrm{C} 1$ & $\mathrm{D} 1$ \\
\hline 2 & $\mathrm{~A} 2$ & $\mathrm{~B} 2$ & $\mathrm{C} 2$ & $\mathrm{D} 2$ \\
\hline
\end{tabular}

Keterangan :
1,2 : Ulangan
A : Formula Mie Basah 1 (Terigu 100\%/Kontrol)
B : Formula Mie Basah 2 (Terigu 80\%, Mocaf 20\%, Rebon 10\%)
C : Formula Mie Basah 3 (Terigu 80\%, Mocaf 20\%, Rebon 15\%)
D : Formula Mie Basah 3 (Terigu 80\%, Mocaf 20\%, Rebon 20\%)

Uji Organoleptik menggunakan form uji hedonic. Panelis yang digunakan mahasiswa tingkat III Program Studi DIII Gizi Cirebon sebanyak 26 orang yang bersedia menjadi panelis dan mempunyai tingkat kesukaan yang relatif sama. Untuk itu penulis melakukan seleksi panelis dengan menggunakan kuesioner penampisan penelis untuk mengetahui tingkat kesukaan penelis terhadap mie sehat. Penulis tidak akan mengambil calon panelis yang tidak menyukai mie basah. Instrument yang digunakan untuk mendapatkan komposisi zat gizi Mie Sehat adalah program Nutrisurvey dan dilakukan untuk mengetahui komposisi zat gizi Mie Sehat terpilih.
Uji daya terima dilakukan pada kelompok sasaran (anak sekolah) melalui pengamatan terhadap kesukaan dan jumlah porsi makanan kudapan yang mampu dihabiskan serta ekspresi dan tanggapan yang diberikan. Pengamatan dilakukan terhadap 25 (dua puluh lima) orang anak sekolah (10-12 tahun) dengan satu kali pemberian. Pengujian dilakukan di Sekolah Dasar yang ada di kota Cirebon.

Data uji organoleptik yang didapat dari 26 panelis dianalisis dengan teknik statistik parametrik dengan uji Anova, jika ada perbedaan yang signifikan dilanjutkan dengan uji lanjut Duncan untuk mengetahui formula terbaik..

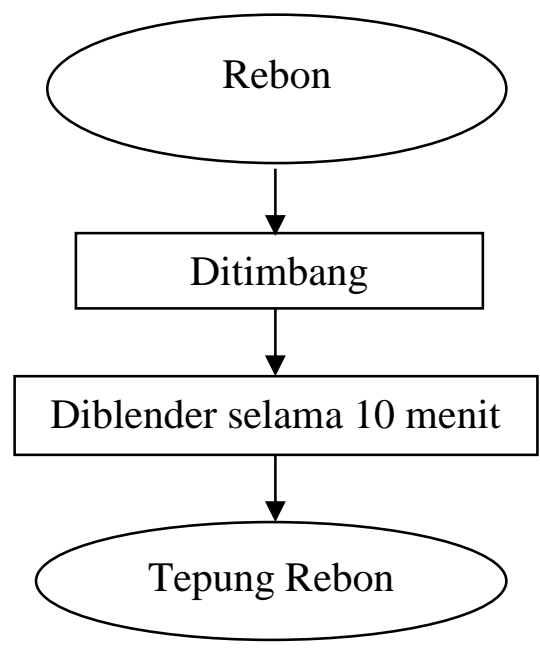

Gambar 1. Diagram Alir Proses Pembuatan Tepung Rebon 


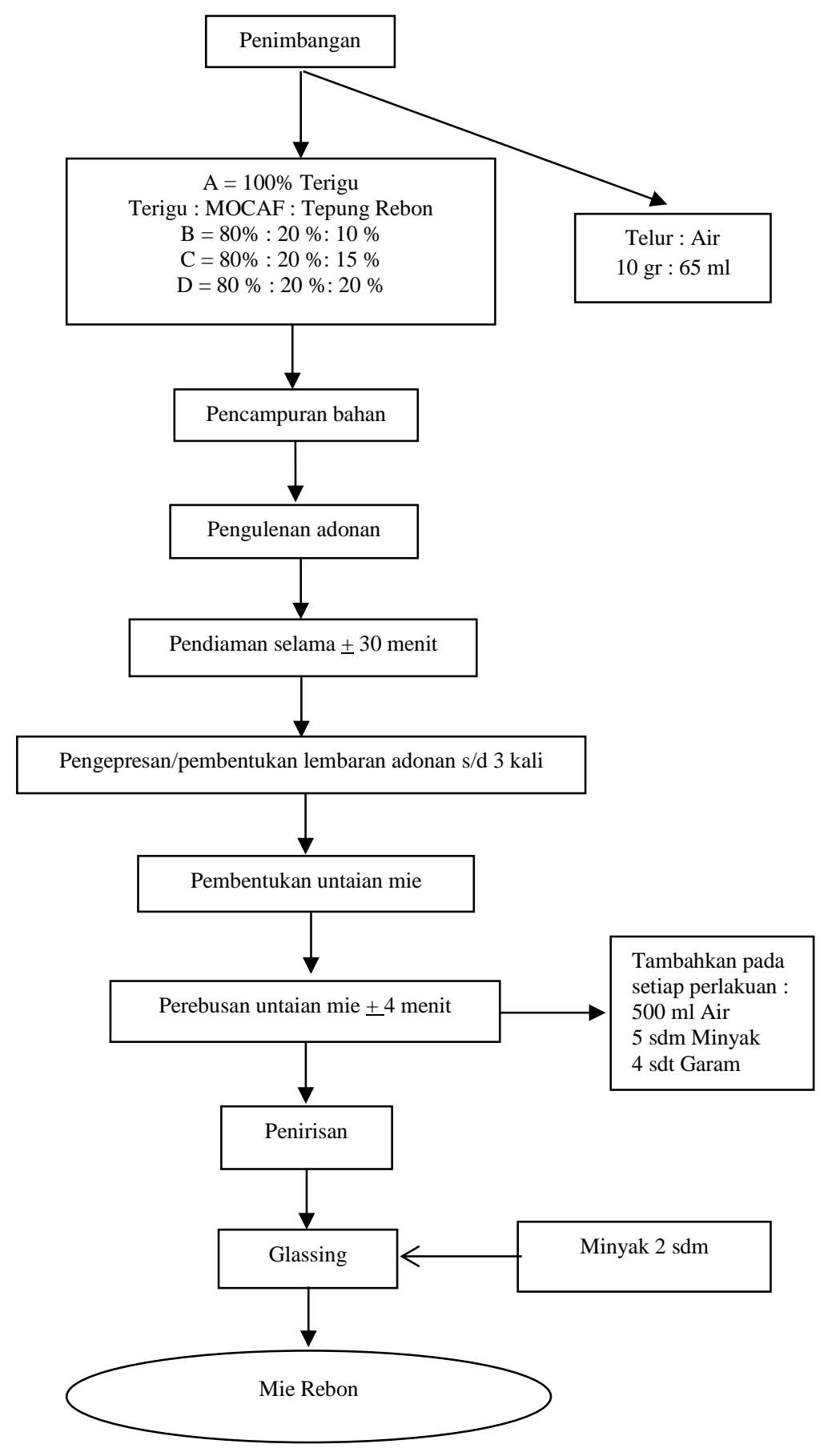

Gambar 2. Diagram Alir Proses Pembuatan Tepung Rebon 


\section{HASIL PENELITIAN}

\section{A. Warna}

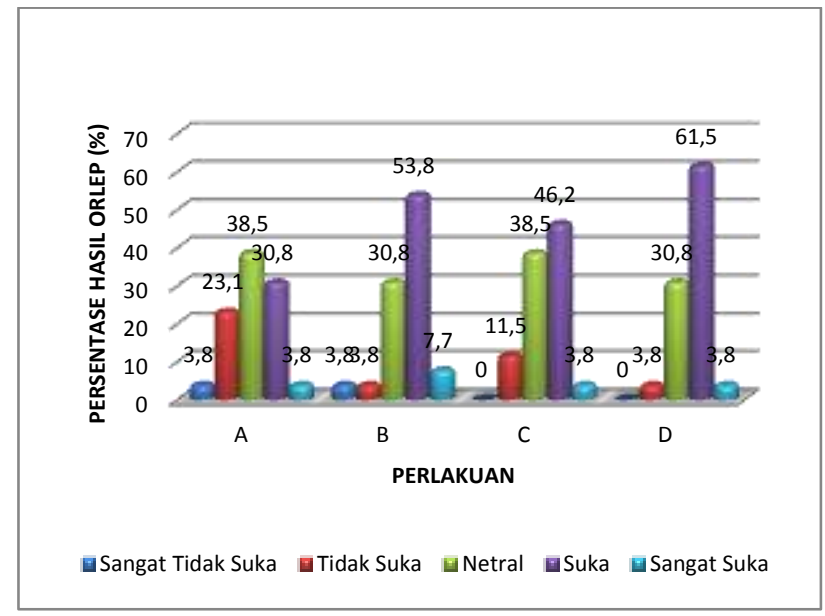

Gambar 3. Hasil uji organoleptik warna produk mie rebon

Warna produk pangan sangat menentukan penerimaan atau penolakan konsumen terhadap produk tersebut (Wirdayanti, 2012). Berdasarkan persentase hasil organoleptik,secara umumpanelis menerima warna dari produk Mie Rebon. Hal ini terjadi karena mie rebon yang dibuat memiliki warna yang hampir sama seperti warna mie pada umumnya yaitu berwarna putih kekuningan.

Penerimaan panelis terhadap warna mie rebon dapat dilihat pada Gambar 3 . Berdasarkan gambar tersebut $38.5 \%$ panelis menyatakan netral terhadap warna mieperlakuan A, 53.8\% panelis menyatakan suka pada warna mie perlakuan B, $46.2 \%$ panelis menyatakan suka pada warna mie perlakuan $\mathrm{C}$ dan $61.5 \%$ panelis menyatakan suka pada warna mie perlakuan D.Perlakuan D dengan penambahan 20\% rebon memiliki persentase kesukaan paling tinggi dibandingkan perlakuan yang lain.

Dari hasil uji statistik Kruskal Wallis menunjukkan bahwa penambahan rebon tidak memberikan pengaruh yang bermakna $(p>0,05)$ terhadap warna produk Mie Rebon.

\section{B. Aroma}

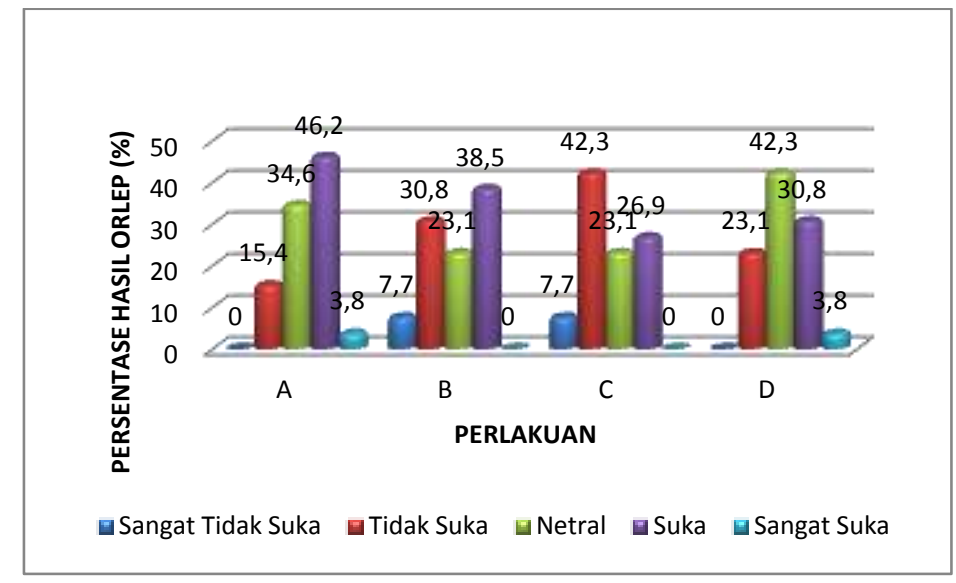

Gambar 4. Hasil uji organoleptik aroma produk mie rebon 
Aroma meruapakan komponen bau yang ditimbulkan oleh suatu produk yang teridentifikasi oleh indera pencium.Aroma makanan banyak menentukan kelezatan bahan makanan tersebut (Affy, 2007). Berdasarkan persentase hasil organoleptik, hampir semua panelis menerima atau menyukai aroma dari produk mie rebon. Hal ini terjadi karena mie rebon yang dibuat memiliki aroma rebon yang tidak terlalu menyengat. Hanya saja $42.3 \%$ panelis menyatakan tidak suka terhadapa mie perlakuan C (penambahan 15\% rebon).

Penerimaan panelis terhadap aroma mie rebon dapat dilihat pada Gambar 4.
Berdasarkan gambar tersebut $46.2 \%$ panelis menyatakan suka terhadap aromamie perlakuan $\mathrm{A}, 38.5 \%$ panelis menyatakan suka pada aroma mie perlakuan B, $42.3 \%$ menyatakan tidak suka pada aroma mie perlakuan $C$ dan $42.3 \%$ panelis menyatakan suka pada aroma mie perlakuan $D$. Perlakuan $\mathrm{A}$ dengan penambahan $0 \%$ rebon (kontrol) memiliki persentase kesukaan paling tinggi dibandingkan sampel yang lain.

Dari hasil uji statistik Kruskal Wallis menunjukkan bahwa penambahan rebon tidak memberikan pengaruh yang bermakna $(p>0,05)$ terhadap aroma produk Mie Rebon.

\section{Rasa}

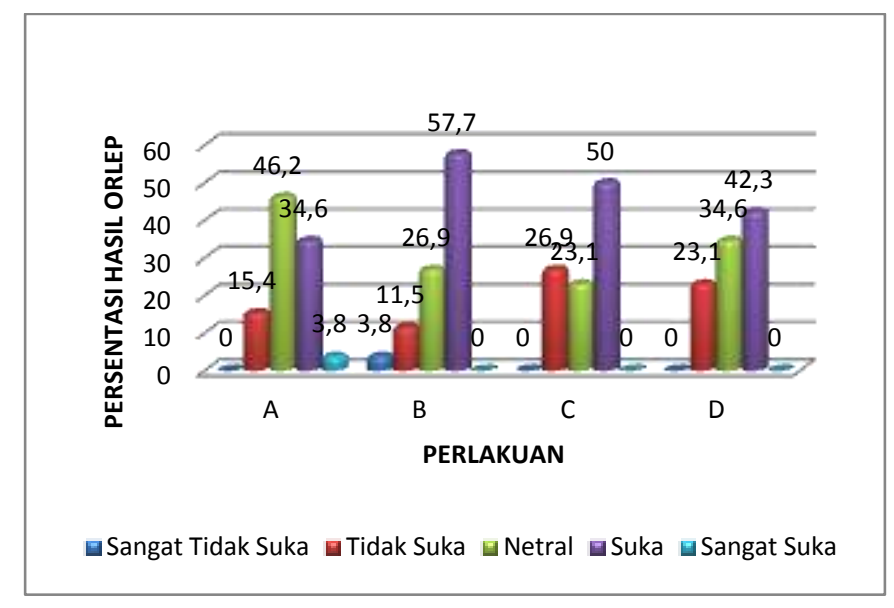

Gambar 5. Hasil uji organoleptik rasa produk Mie Rebon

Rasa didefinisikan sebagai rangsangan yang ditimbulkan oleh bahan yang dimakan, terutama yang dirasakan indera pengecap. Rasa merupakan faktor penting dalam menentukan keputusan bagi konsumen untuk menerima atau menolak makanan (Diniyati, 2012).

Berdasarkan persentase hasil organoleptik, hampir semua panelis menerima atau menyukai rasa dari produk mie rebon, meskipun dalam pembuatan mie rebon tidak menggunakan penyedap atau bumbu tambahan, dengan penambahan rebon membuat mie memiliki rasa gurih dan asin yang berasal dari rebon itu sendiri sehingga hampir semua panelis menyukai rasa dari mie rebon.
Penerimaan panelis terhadap rasa mie rebon dapat dilihat pada Gambar 6 . Berdasarkan gambar tersebut $46.2 \%$ panelis menyatakan netral terhadap rasa mie perlakuan A, $57.7 \%$ panelis menyatakan suka pada rasa mie perlakuan B, $50 \%$ menyatakan suka pada rasamie perlakuan C dan $42.3 \%$ panelis menyatakan suka pada rasamie perlakuan D. Perlakuan B dengan penambahan $10 \%$ rebon memiliki persentase kesukaan paling tinggi dibandingkan sampel yang lain. Dari hasil uji statistik Kruskal Wallis menunjukkan bahwa penambahan rebon tidak memberikan pengaruh yang bermakna $(p>0,05)$ terhadap rasa produk mie rebon. 


\section{Tekstur}

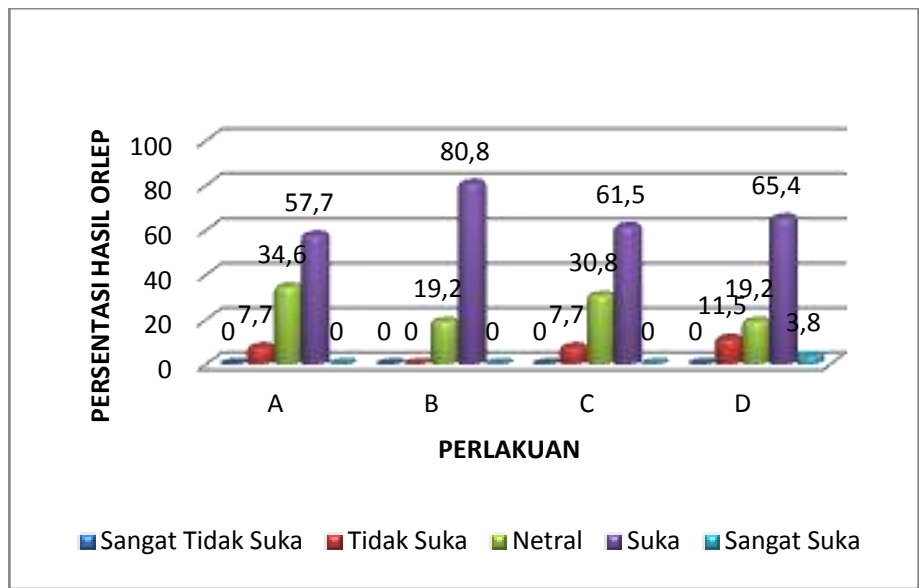

Gambar 6. Hasil uji organoleptik teksturproduk Mie Rebon

Tekstur merupakan komponen yang turut menentukan cita rasa makanan, karena sensitifitas indera perasa dipengaruhi oleh tekstur atau konsistensi makanan. Makanan yang konsistensinya adat atau kental, lunak atau keras akan memberikan rangsangan yang lebih lembut terhadap indera. Pada suatu makanan dapat dilihat dari segi kelembaban, kekeringan, kerapuhan, kekerasan dan kelembutan dari makanan (Buckle, 1987 dlm Nurman, 2010).

Berdasarkan persentase hasil organoleptik, semua panelis menerima atau menyukai tekstur dari produk mie rebon, hal ini terjadi karena tekstur mie rebon hampir serupa dengan tekstur mie pada umumnya yaitu bertekstur kenyal. Penerimaan panelis terhadap rasa mie rebon dapat dilihat pada Gambar 6. Berdasarkan gambar tersebut $57.7 \%$ panelis menyatakan suka terhadap teksturmie perlakuan A, $80.8 \%$ panelis menyatakan suka pada teksturmie perlakuan $\mathrm{B}, 61.5 \%$ menyatakan suka pada teksturmie perlakuan C dan $65.4 \%$ panelis menyatakan suka pada teksturmie perlakuan D. Perlakuan B dengan penambahan $10 \%$ rebon memiliki persentase kesukaan paling tinggi dibandingkan sampel yang lain. Dari hasil uji statistik Kruskal Wallis menunjukkan bahwa penambahan rebon tidak memberikan pengaruh yang bermakna $(p>0,05)$ terhadap tekstur produk Mie Rebon.

\section{E. Penampilan keseluruhan}

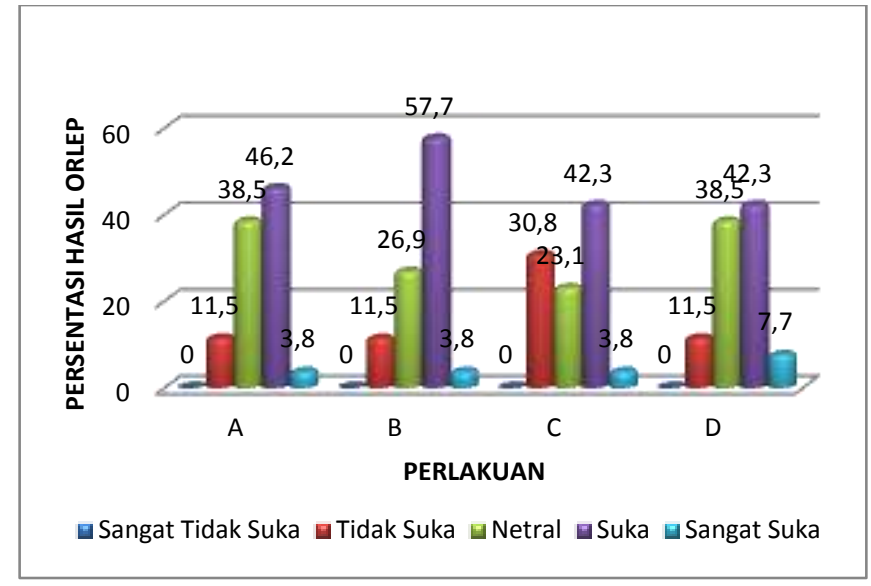

Gambar 7. Hasil uji organoleptik penampilan keseluruhan produk mie rebon 
Secara keseluruhan, semua panelis menyukai seluruh Mie Rebon yang dibuat. Dapat dilihat pada Gambar8, $46.2 \%$ panelis menyatakan suka terhadap mie rebon perlakuan A, $57.7 \%$ panelis menyatakan suka pada mie rebon perlakuan B, $42.3 \%$ panelis menyatakan suka pada mie rebon perlakuan $C$ dan $42.3 \%$ panelis menyatakan suka mie rebon perlakuan D. Secara

\section{KESIMPULAN}

Berdasarkan penelitian dengan judul Pengembangan Makanan Jajanan Anak Sekolah Mie Rebon Berbahan Dasar Tepung Mocaf (Modified Cassava Flour) dan Rebon serta Uji Organoleptik diperoleh hasil sebagai berikut:

1. Empat formulasi dasar dari produk mie rebon adalah formulasi mie rebon 1 tepung terigu $100 \%$, formulasi Mie Rebon 2 tepung terigu $80 \%$, tepung mocaf MOCAF $20 \%$, Rebon $10 \%$, formulasi Mie Rebon 3 tepung terigu $80 \%$, tepung mocaf MOCAF $20 \%$, Rebon $15 \%$, dan formulasi Mie Rebon 4 tepung terigu $80 \%$, tepung mocaf MOCAF $20 \%$, Rebon $20 \%$.

\section{SARAN}

Perlu dilakukan penelitian lanjutan untuk membuat mie dalam bentuk mie kering agar daya simpan mie lebih lama

\section{DAFTAR PUSTAKA}

Affy, S. 2007. Produksi Mie Kering Dari Ubi Jalar (Ipomea Batatas) Varietas Unggulan. Skripsi. Bogor: Institut Pertanian Bogor.

Almatsier, Sunita. 2000. Prinsip Dasar IImu Gizi. Jakarta. Gramedia Pustaka Utama.

Andarwulan, Nuri.dkk. 2011. Analisis Pangan. Dian Rakyat. Jakarta.

AOAC, 1984. Official of Analisis of the Association of Official Analytical Chemist, 14 th ed. AOAC, INC. Arlington, Virginia. .

Diniyati, B. 2012. Kadar Betakaroten, Kadar Protein, Tingkat Kekerasan, Dan Mutu Organoleptik, Mie Instan Dengan keseluruhan mie rebon perlakuan $\mathrm{B}$ dengan penambahan $10 \%$ rebon memiliki persentase kesukaan paling tinggi dibandingkan sampel yang lain. Dari hasil uji statistik Kruskal Wallis menunjukkan bahwa penambahan rebon tidak memberikan pengaruh yang bermakna $(p>0,05)$ terhadap penampilan keseluruhan produk Mie Rebon.

2. Sifat organoleptik produk mie rebon dari segi warna, aroma, rasa, tekstur, dan penampilan keseluruhan tidak berpengaruh nyata.

3. Tingkat kesukaan produk mie rebon dari segi warna yaitu mie rebon 4 sebesar $1.5 \%$, dari segi aroma yaitu mie rebon 1 sebesar $46.2 \%$, dari segi rasa yaitu mie rebon 2 sebesar $57.7 \%$, dari segi tekstur yaitu mie rebon 2 sebesar $80.8 \%$, dari segi penampilan keseluruhan yaitu mie rebon 2 sebesar $57.7 \%$.

4. Mie rebon terbaik adalah mie rebon 2 dengan formulasi tepung terigu $80 \%$, Mocaf 20\%, dan Rebon 10\%.

dan produk tersebut dapat dijadikan alternatif cemilan sehat bagi anak sekolah.

Substitusi Tepung Ubi Jalar Merah (Ipomea Batatas) dan Kacang Hijau (Vigna Radiata). Skripsi. Semarang: Universitas Diponegoro.

Nelson, Adry. 2013. Tepung Mocaf Produk Ketahanan Pangan Masa Depan

Nurman, Z. 2010. Daya Terima Formula Makanan Tambahan Berbahan Dasar Tepung Ubi Jalar Merah (Ipomea Batatas L) Ikan Nila (Oreochromis Niloticus) Dan Kacang Merah (Phaseolus Vulgaris L) Untuk Anak Balita. Skripsi. Padang: Politeknik Kesehatan Depkes RI Padang

Putra, Adi. 2007. Aplikasi Kombinasi Bubuk Fuli Pala (Myristica Fragrans Houtt) 
Dan NaCL Sebagai Pengawet Alami Pada MiBasah Matang. Skripsi. Bogor: Institut Pertanian Bogor.

Rahayu W. P. 1998. Penuntun Praktikum Penilaian Organoleptik. Jurusan Teknologi Pangan dan Gizi, FATETA, IPB, Bogor.

Ratnawati, Vanny Riski. 2011. Pengaruh Variasi Penbamahan Lidah Buaya (Aloe vera) dalam Pembuatan Agaragar dirinjau dari Sifat Fisik, Organoleptik dan Kadar Beta-Karoten. Karya Tulis IImiah. Yogyakarta: Politeknik Kesehatan Kemenkes Yogyakarta.

Rini, Ari Widyas. 2008. Pengaruh Penambahan Tepung Koro Glinding (Phaseolus Lunatus) terhadap Sifat Kimia dan Organoleptik Mi Basah dengan Bahan Baku Tepung Terigu yang Disubstitusi Tepung Ubi Jalar Ungu (Ipomoea Batatas). Skripsi. Surakarta: Universitas Sebelas Maret.

Sudarmadji, S, Bambang $\mathrm{H}$, dan Suhardi. 1997. Prosedur Analisa Untuk Bahan Makanan dan Pertanian. Liberty. Yogyakarta.

Wirdayanti, 2012. Studi Pembuatan Mie Keringdenganpenambahanpasta Ubi Jalar (Ipomoea Batatas),Pasta Kacang Tunggakdan Pasta Tempe Kacang Tunggak (Vigna Unguiculata,L). Skripsi. Makassar: Universitas Hasanudin.

Zulaidah, Agustien. 2011. Modifikasi Ubi Kayu Secara Biologi Menggunakan Starter Bimo-Cf Menjadi Tepung Termodifikasi Pengganti Gandum. Thesis. Semarang: Universitas Diponegoro 